\title{
Continuing Health Education in elderly care: difficulties and facilitators of the Family Health Support Center*
}

Educação Permanente em Saúde na atenção ao idoso: dificuldades e facilidades do Núcleo de Apoio à Saúde da Família

\author{
Educación Permanente en Salud en la atención al anciano: dificultades y facilidades del Núcleo de \\ Apoyo a la Salud de la Familia
}

lara Sescon Nogueira ${ }^{1}$ (D)

Vanessa Denardi Antoniassi Baldissera ${ }^{1}$

1. Universidade Estadual de Maringá.

Maringá, PR, Brasil.
Corresponding author:

lara Sescon Nogueira.

E-mail: iara_nogueira@hotmail.com

Submitted on $02 / 05 / 2018$.

Accepted on 04/19/2018.

DOI: 10.1590/2177-9465-EAN-2018-0028

\begin{abstract}
Objectives: To analyze the difficulties and facilitators of Continuing Health Education developed by the Núcleos de Apoio à Saúde da Familia (NASF - Family Health Support Centers) in elderly care. Method: A qualitative and exploratory-descriptive study was developed with 46 NASF professionals. Data were obtained with the Focus Group technique and analyzed with basic lexicography using the IRaMuTeQ ${ }^{\circledR}$ software, through Word Clouds. The theoretical-analytical framework adopted was Freire's Dialogical Theory. Results: The difficulties of Continuing Health Education in elderly care were experienced more frequently than facilitators, which were associated with lack of support, instruments and resources. Conclusion and implications for practice: Portraying Continuing Health Education can contribute to the reflection, planning and evaluation of educational practices and elderly care practiced by the NASF.
\end{abstract}

Keywords: Primary Health Care; Continuing Education; Elderly Care; Public Health Policies.

\section{Resumo}

Objetivos: Analisar as dificuldades e facilidades da Educação Permanente em Saúde desenvolvida pelo Núcleo de Apoio à Saúde da Família na atenção ao idoso. Método: Estudo qualitativo e exploratório-descritivo, desenvolvido com 46 profissionais do Núcleo de Apoio à Saúde da Família. Os dados foram obtidos pela técnica de Grupo Focal e analisados por lexicografia básica utilizando o software IRaMuTeQ ${ }^{\circledast}$, por meio da Nuvem de Palavras. O referencial teórico-analítico adotado foi a Teoria Dialógica de Freire. Resultados: As dificuldades de Educação Permanente em Saúde na atenção ao idoso são mais vivenciadas do que as facilidades, e relacionou-se a falta ou ausência de apoio, ferramentas e subsídios. Conclusão e implicações para a prática: Retratar o universo da Educação Permanente em Saúde poderá contribuir com os movimentos de reflexão, planejamento e avaliação das práticas educativas e assistenciais acerca da saúde do idoso, praticadas pelo Núcleo de Apoio à Saúde da Família.

Palavras-chave: Atenção Primária à Saúde; Educação Continuada; Saúde do Idoso; Políticas Públicas de Saúde.

\section{Resumen}

Objetivos: Analizar dificultades y facilidades de la Educación Permanente en Salud desarrollada por el Núcleo de Apoyo a la Salud de la Familia en atención al anciano. Método: Estudio cualitativo, exploratorio-descriptivo, desarrollado con 46 profesionales del Núcleo de Apoyo a la Salud de la Familia. Los datos fueron obtenidos por la técnica de Grupo Focal y analizados por lexicografía básica utilizando el software IRaMuTeQ ${ }^{\circledR}$, por medio de Nube de Palabras. El referencial teórico-analítico adoptado fue la Teoría Dialógica de Freire. Resultados: Las dificultades son más vivenciadas que las facilidades; se relacionó la falta o ausencia de apoyo, herramientas y subsidios. Conclusión e implicaciones para la práctica: Retratar el universo de la Educación Permanente en Salud podrá contribuir en los movimientos de reflexión, planificación y evaluación de las prácticas educativas y asistenciales de salud del anciano en el Núcleo de Apoyo a la Salud de la Familia.

Palabras clave: Atención Primaria de Salud; Educación Continuada; Salud del Anciano; Políticas Públicas de Salud. 


\section{INTRODUCTION}

The Núcleos de Apoio à Saúde da Família (NASF - Family Health Support Centers) are comprised of professionals from different areas of knowledge whose work is integrated with Estratégia Saúde da Família (ESF - Family Health Strategy) teams, sharing practices and knowledge about health and contributing to the improvement in quality and resolvability of Primary Health Care (PHC) actions. ${ }^{1}$

NASF presuppositions are regulated by the matrix support for ESF teams, based on the local needs and through shared and inter-professional services. ${ }^{1}$ Thus, the NASF and ESF qualify $\mathrm{PHC}$ which, in its turn, becomes a privileged structuring environment for teaching and learning in the workplace, revealing the locus of Continuing Health Education (CHE).

As a relevant policy, PHE takes into consideration professionals who are active in their work fields, where learning and teaching are incorporated into the routine of organizations and into the work. This is based on meaningful learning and the possibility of transforming professional practices and the work organization itself, ${ }^{2-4}$ an essential strategy for quality in health care, breaking away from the fragmentation of care and developing services. ${ }^{5}$

Thus, it could be inferred that the NASF, interacting with the ESF and contributing to the qualification of $\mathrm{PHC}$ through the exchange of knowledge and practices defined by the concrete work reality, includes attributions in agreement with Continuing Health Education (CHE) principles as it has an educational potential with ESF professionals. These transformative educational attributions build group knowledge ${ }^{1}$ and, in this sense, the matrix support provided by the NASF is one of the most evident means to create an ESF team. ${ }^{1,6}$

Regarding elderly health and considering the magnitude of population aging, care for older adults must be provided in a comprehensive way, which must include multiprofessional services. However, the practices developed by the ESF team have a limited reach. As a result, the technical-educational support provided by the NASF is relevant, through the matrix support in the strategical area of comprehensive care/ rehabilitation of older adults, considering the epidemiological, cultural and socioeconomic reality of the population cared for and, especially, the joint planning with the ESF teams supported by these centers. ${ }^{1}$

Health promotion, prevention and treatment actions for older adults depend on the development of health professional competences in comprehensive care in the perspective of inter-professional team work practice, suggesting an interaction between ESF and NASF as a way to improve elderly care. ${ }^{7}$

Professional qualification in aging management is still restricted to healing actions, mischaracterizing the main ESF demand centered on health prevention and promotion, according to presuppositions of active and healthy aging. ${ }^{8}$ It should be emphasized that the health services provided to this population need adequate coping strategies, as acute and chronic condi- tions, senility and senescence coexist ${ }^{7,8}$ and require skillful and competent professionals.

Thus, the work of the NASF with the ESF is essential, especially due to the matrix support that directs and improves elderly care. In this sense, the dialogical interaction that transforms knowledge and practices is a prerogative which is coherent with the proposals of health care shared between the ESF and NASF. This causes learning and doing to be indissoluble, founded on the praxis that evidences actionreflection-action. ${ }^{9,10}$

Consequently, the interaction of knowledge with actions between NASF and ESF can develop the actions and care for older adults, working as an educational strategy of this team to qualify it. ${ }^{1}$ In this sense, $\mathrm{PHE}$, where authentic dialogue ${ }^{9,10}$ about elderly care takes place, is relevant and necessary, especially because it considers the close relationship between the principles of the Política Nacional de Educação Permanente em Saúde (PNEPS - National Policy on Continuing Health Education), ${ }^{2}$ the NASF attributions ${ }^{1}$ and this theoretical framework.

However, there is a gap between PHE and its implementation, including challenges that hinder its development, ${ }^{11}$ especially in elderly care. Thus, the following question arose: What are the main difficulties and facilitators experienced by NASF professionals to develop PHE for elderly care with ESF teams? As a result, the present study aimed to analyze the difficulties and facilitators of PHE practices developed by the NASF in the context of elderly care.

\section{METHODS}

An exploratory-descriptive study with a qualitative approach and an analytical-interpretative nature was performed in a city in the Mid-North Paraná state, Southern Brazil. The target population of the present study included 53 health professionals participating in the nine NASF centers found in this city.

The inclusion criteria for the present study were as follows: to be a NASF professional; to have worked in 2016; and to be performing their tasks in the NASF during data collection. All professionals participating in the NASF in the city in question who met the inclusion criteria were invited to participate in this study, through a previous contact and pre-arranged meeting. In contrast, the exclusion criteria were as follows: professionals who belonged to the NASF team targeted by the pilot test used to adequate the data collection instrument. Thus, a total of 46 health professionals included in eight NASF teams participated in the present study.

Data were collected between February and April 2017 using the Focus Group (FG) technique, ${ }^{12}$ which is comprised of a group discussion where the interaction of participants enables different points of view to be explored from reflections. This promotes problematization and allows participants to reflect over the difficulties and facilitators of PHE practices aimed at elderly care developed by each of them. 
The data collection instrument was a set of guidelines developed by the researchers and comprised of triggering questions that promoted FG discussions. Additionally, these questions were about PHE practices aimed at elderly care developed by NASF professionals, apart from socio-demographic and professional questions for the characterization of study participants. These guidelines were previously adapted by judges and a pilot $F G$, aiming to guarantee methodological accuracy and to prevent bias.

Thus, a FG was conducted by the NASF, totaling eight groups named from FG1 to FG8. These FGs were held in the workplace and shift of professionals through a previous appointment, lasting 49 minutes on average and including from four to seven participants.

It should be emphasized that the FGs included the following professionals: FG1: a psychologist, a speech therapist, a physiotherapist, a physical educator and a nutritionist; FG2: a social worker, a nutritionist, a physiotherapist, a psychologist, a pharmacist, and a physical educator; FG3: a nutritionist, a social worker, a pharmacist, an occupational therapist, a speech therapist, and a psychologist; FG4: an occupational therapist, a physiotherapist, a physical educator, a psychologist, a speech therapist and a nutritionist; FG5: an occupational therapist, a nutritionist, a social worker, a physiotherapist, a physical educator, a psychologist, and a speech therapist; FG6: a physiotherapist, a nutritionist, a pharmacist, a social worker, a psychologist, a physical educator and a speech therapist; FG7: a speech therapist, a psychologist, a physical educator, a nutritionist and a pharmacist; and FG8: a nutritionist, a psychologist, and two social workers.

It should be emphasized that the make-up of each NASF team is heterogeneous, varying according to what has been defined by city managers, considering the priority criteria identified from epidemiological data, the needs of the area and the ESF teams that are supported. ${ }^{1}$ This make-up was reflected in the organization of the FGs with distinct professional participations, as previously mentioned. However, the results found were not influenced, as the present study was centered on the NASF team's perspective of the phenomenon analyzed, regardless of the professional categories comprising each team.

Data on participant characterization were processed with the Microsoft Excel $2010^{\circledR}$ software and analyzed using simple descriptive statistics.

Aiming to organize, treat and analyze data, FG discussions were recorded on audio, fully transcribed by researchers and analyzed through basic lexicography using the Interface de $R$ pour les Analyses Multidimensionnelles de Textes et de Ques tionnaires $\left(\mathrm{IRaMuTeQ}{ }^{\circledast}\right)^{13}$ software. Through this software, Word Clouds were created, an analysis mechanism including the application that makes simple lexical analyses, organizing words in a graphic way according to frequency of appearance in speech, based on an archive known as corpus. ${ }^{13}$ Each FG characterized a text and the set of texts referring to the difficulties and facilitators comprised the corpus of analysis in this study.
Aiming to meet the research objective, these texts were organized into two corpus, one about the reports of difficulties encountered by NASF professionals to develop PHE in elderly care (corpus one) and another about the facilitators experienced by the same individuals (corpus two), thus generating two word clouds that were used for interpretative analysis of the words presented.

This study used Freire's Dialogical Theory ${ }^{9,10}$ as theoreticalanalytical framework in terms of the transformation of knowledge and practices permeated by authentic dialogue.

All ethical and legal principles established by Resolution 466/2012 of the National Health Council were met. ${ }^{14}$ Aiming to guarantee participants' anonymity, their reports were identified by the acronym "FG", standing for "Focus Group", followed by a number that corresponded to the order in which FGs were performed.

This study was part of a broader research project and it was submitted for the ethical appreciation of the Research Ethics Committee of the State University of the city in question, obtaining the favorable official opinion number 1.948.003/2017 (CAAE: 47111915.5.0000.0104).

\section{RESULTS}

\section{Characterization of Participants}

A total of 46 professionals included in the NASF participated in the present study. There was a predominance of women $(n=39)$. Age ranged from 24 to 61 years, with a mean of 34.8 years. Regarding profession, eight participants were nutritionists, eight were psychologists, six were physical educators, six were social workers, six were speech therapists, five were physiotherapists, four were pharmacists, and three were occupational therapists. Length of time since qualification varied from three to 41 years, with a mean of 10.4 years, while the length of time working in the NASF varied from six months to eight years, with a mean of three years and eight months.

Aiming to discuss the facilitators and difficulties of PHE developed by the NASF, we must show what these activities are according to participants, although in a general way, so that they can be contextualized. Thus, PHE moments in elderly care were taken into consideration: case discussion, matrix support triggered by the management initiative, home visits, performance in health education groups, and the informal dialogue enabled by the work routine.

\section{Difficulties encountered by Family Health Support Center professionals to develop Continuing Health Education in elderly care}

Regarding the difficulties found, the word "no" did not show a higher frequency in corpus one $(n=137)$, followed by the word "team" ( $n=62)$, represented in the cloud as equipa (Portuguese from Portugal). In the sequence, the most frequent words were as follows: lack $(n=43)$, being $(n=38)$ and work $(n=26)$ (Figure 1). 
Figure 1. Word Cloud: difficulties encountered by NASF professionals to develop PHE in elderly care in a city in the Mid-North Paraná state, Brazil, 2017. Source: The authors (2017). Designed with the IRaMuTeQ ${ }^{\circledR}$ software.

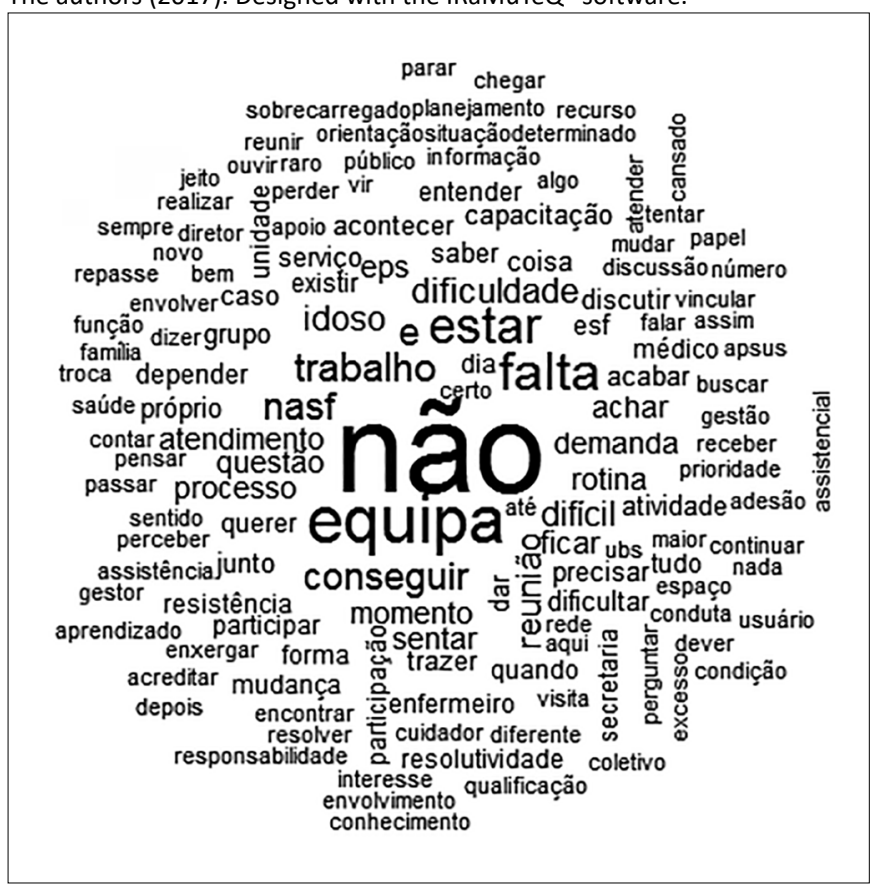

Regarding the word "no", participants reported that PHE in elderly care does not often occur or it is not a priority, as there is not enough time for its development due to an excess of health care activities to the detriment of educational moments:

The difficulty is that the Department of Health does not understand that this is important, as the priority is elderly care [...] We don't have time for this, because the goal is to serve. (FG8)

This is never given priority as everything that happens in this unit, whether it's an emergency, health care services or consultations, is prioritized. So we leave PHE for later [...] PHE in elderly care is not a priority. (FG7)

NASF meetings, which are also seen as opportune moments to develop PHE in elderly care, could not be performed in a certain moment due to the management/manager's orders. This lack of meetings prevents the development of spaces for dialogue, reflection and learning, as observed in the reports below:

We've had UBS (Primary Health Units) managers who simply said that there'd be no meetings. (FG2)

Our meetings are not well regarded by the city's department of health. We've even been instructed that meetings are not a priority, the services and the group are our priority [...] It's a NASF role, but our department is not integrated with PHE. (FG5)
Additionally, NASF professionals felt discouraged with PHE in elderly care. This was especially associated with the service's lack of resolvability and the network's incapacity to care for the elderly population. Thus, they reported that they lose interest in the development of educational practices in the sphere of PHE with the ESF, in the sense of transforming knowledge and practices, as they find obstacles. According to them, there are no available resources to continue providing health care, as evidenced in the following reports:

We try to refer elderly individuals. The team cannot resolve this, exactly because of this flow of services, this delay. This is a great obstacle, professionals lose interest in PHE as there is no resolvability. (FG6)

Elderly individuals need a service for social interaction, for example, but there are no vacancies for them and no resources. When we promote PHE, we understand that the team will ask what we are going to do and this is frustrating for them. (FG7)

The difficulties found in team work were also evidenced, as well as the word "team", in the sense of the partial existence of shared work between the NASF and ESF, which promotes new knowledge and activities in the context of elderly care. As a difficulty, the NASF perceived the resistance of ESF professionals to share educational moments in elderly care, reporting that the lack of understanding, participation and involvement of the ESF team hinders the occurrence of such educational moments:

To make the teams stop their activities and understand this moment of discussion, of listening and being there for learning, this is very difficult. We rarely manage to gather the team and they understand the importance of dialogue to build something together. (FG3)

It's difficult for the team to be involved, because not all of them see this the same way, with the same willingness to sit together, discuss and learn. (FG5)

Professionals also attribute difficulties such as the Unidades Básicas de Saúde (UBS - Primary Health Units) directors' and even the management's lack of support and understanding of the actual role and function of NASF professionals. This lack of understanding, also seen among some of the professionals, due to their undefined roles, causes them to perform activities that are not in agreement with their main characteristic, which is to provide health practice support to the ESF:

Directors and managers don't have enough understanding of the activities that the NASF should develop. These directors and some professionals don't have enough knowledge about NASF policies. (FG2) 
There's not enough understanding of the most recent proposals of PHC functioning. Many professionals work with more traditional health care models, so that our proposal doesn't to make sense. (FG4)

Additionally, the fact that health professionals cannot be together was found to be another obstacle for PHE in the praxis with the NASF. The word "being" meant the moment when the NASF and ESF teams met to work together. However, these moments are described by study participants as difficult, in the sense of professionals finding and saving a common time to be together:

It's difficult to be together, it used to be once a week, now we struggle to meet once a month. (FG6)

It's hard to find a moment to meet. [...] It's difficult to set up a time to be together. (FG7)

The work process was also pointed out as one of the main difficulties for PHE in the context of PHC and elderly care. Work overload, excessive health service activities imposed by the hegemonic medical care model, multiple functions and the lack of professionals hinder and often prevent PHE:

Thinking about the things we've done, in the units we're in, in the different activities we perform, in the number of services provided... The work process does not contribute because it's too broad, the demand is high and there are many UBS. The team is not complete, which also hinders PHE in elderly care and overwhelms professionals. (FG8)

Excessive health care services. Excessive reports to write, so we can't focus on PHE in elderly care. Our minds are not open to more information. (FG2)

\section{Specific actions that show facilitators experienced by NASF professionals to develop Continuing Health Education in elderly care}

There are facilitators for the development of PHE in elderly care by the NASF, but they are specific. The word "team" showed a higher frequency in corpus two $(n=49)$, followed by the words "elderly" ( $n=33)$, "home visit" ( $n=24)$, "demand" ( $n=20)$, "meeting" $(\mathrm{n}=17)$ and "group" $(\mathrm{n}=17)$ (Figure 2).

The ESF team was emphasized as one of the facilitators to develop PHE and this can be observed by the presence of the word "team" in the central area (Figure 2), showing the emphasis on this word and the positive relationship between teams. The bond, contact, communication, openness, receptivity and partnership among teams are facilitating factors for the occurrence of PHE in elderly care, in addition to the personal interest of each professional, as observed in the following reports:
Figure 2. Word Cloud: facilitators experienced by NASF professionals to develop PHE in elderly care in a city in Mid-North Paraná state, Brazil, 2017. Source: The authors (2017). Designed with the IRaMuTeQ ${ }^{\circledR}$ software.

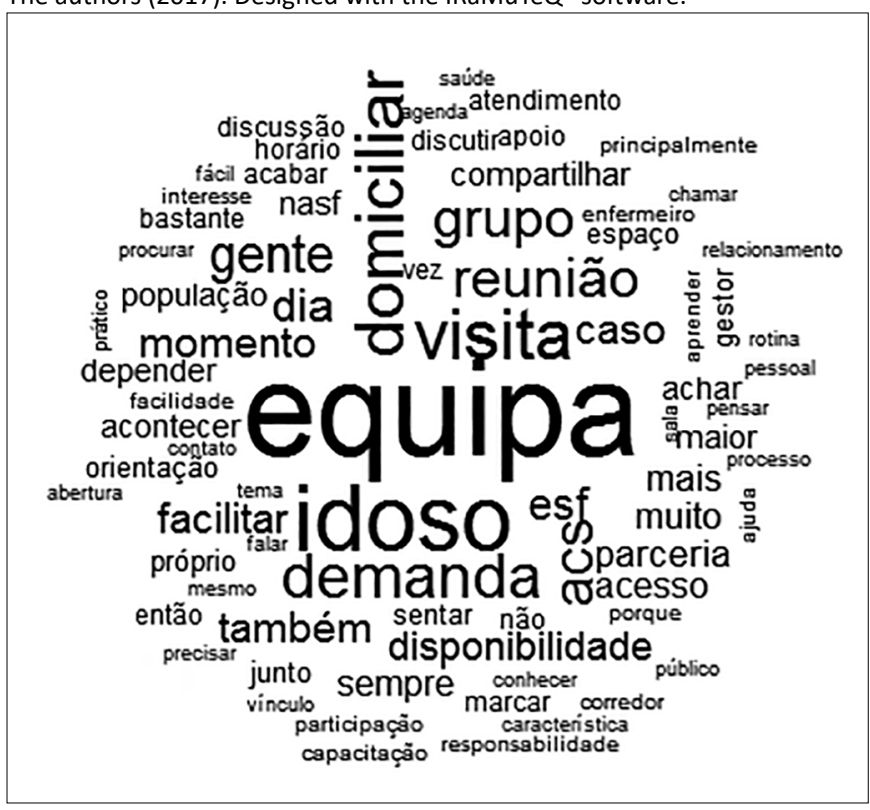

It depends on each team, some teams are more open, others not so much [...] it's easier when there is a better relationship or communication with the team. (FG1)

The fact that a team is open and receptive, this is something we have. This also facilitates PHE in elderly care [...] it requires team co-participation. (FG8)

The word "elderly" represented the target population of the educational and health care activities. According to participants, older adults are the main population cared for, which facilitates the development of PHE practices on this theme due to their frequent presence in several routine work activities:

[...] we managed to choose a theme and work on it, based on elderly care. So, I think this is a facilitator because older adults frequently come to our service. (FG6)

Another word that was frequently found and shown in Figure 2 was "home visit" ( $n=24)$, seen as a facilitator for the development of PHE, as it is already incorporated in the work process of teams. They reported situations when NASF professionals provide instructions to older adults and their families at their home and when an ESF professional is always present, usually a Community Health Agent ( $\mathrm{CHA}$ ), who learns together and begins to incorporate these instructions into their routine practices. Thus, home visits were seen by NASF professionals as an enriching moment to exchange knowledge and transform practices in elderly care: 
During these home visits to elderly patients, we always and preferably bring a CHA [...] it's also at this moment when we're providing care that they are with us, listening to our instructions and learning. (FG1)

The home visits also help! [...] On the way, we discuss cases of elderly patients. On the way back, we share reflections: 'Did you notice this and that?'. The work process itself is a facilitator. (FG2)

The word "demand" ( $n=20$ ) was also frequent (Figure 2). In the perspective of participants, there is a high demand of cases of older adults. based on this demand, the ESF teams seek the NASF to work together, creating moments of PHE in elderly care:

When there is a demand that the team wants to meet, everything works, because in this case they look for us and they're interested in getting answers. Then, the demand for cases of elderly patients becomes a facilitator. (FG4)

When ESF team meetings were held, they were also considered to be a moment of PHE and a facilitator, as this is the time to discuss cases of elderly patients and to exchange knowledge. Additionally, this is a time set up in health professionals' agenda, facilitating their interaction and meeting:

It's much easier when ESF teams are already used to having meetings, because they already meet and organize their time to sit and talk about the health of elderly patients. (FG1)

Moreover, such groups promote the transformation of knowledge and practices in elderly care and they were considered to be opportune moments for PHE. Older adults are the ones who usually participate in these groups, even if they are not aimed at such population:

At the moment when instruction groups are formed in the unit, this becomes a space where PHE in elderly care also takes place. (FG2)

These groups are not specific for elderly people, but most of them are in this age group. So, we end up considering them to be elderly groups, because they are always present. (FG4)

Groups are great facilitators, when there are partnerships with teams and they participate in these groups. (FG5)

Another question raised by study participants is about the municipal health management's direction and support to promote PHE. Although such words were not emphasized, they are equally important. Words such as "training" $(n=8)$, "support" $(n=5)$ and "responsibility" $(n=5)$, found in Figure 2, represented the incentive to municipal guidelines and qualifications. They were considered to be moments when NASF professionals could implement matrix support, understood as PHE, as described in the following reports:

When the 'Programa de Qualificação da Atenção Primária à Saúde" (APSUS - Primary Health Care Qualification Program) was implemented in elderly care, it worked out because it was an initiative of the state and we had to do it. The city bought this idea, gave us tools, told us what we could do, and gave us structure and all. It's different from asking for inside training. It's another type of support. In fact, we need this too, support and commitment from all. (FG8)

\section{DISCUSSION}

The difficulties encountered by NASF professionals to develop PHE in elderly care with the ESF could be shown Excessive health care activities, in addition to work overload, hinders the educational work among professionals, as most of the time is aimed at meeting service demands. These were the most relevant obstacles that affect action-reflection-action moments ${ }^{9}$ during elderly care routine, at times preventing the PHE developed by them. ${ }^{11}$ The consequence is a real obstacle to the transformation of elderly care practices towards healthy and active aging, emphasizing the maintenance of healing actions for this population ${ }^{8}$ and moving away from the NASF's technical-educational role.

Although PHE in elderly care occurs in the work routine, there is the need to establish spaces for dialogue to exchange knowledge, aiming to overcome the fragmentation of professional care $^{7,8,11}$ that prevent authentic meetings ${ }^{9,10}$ for new practices in elderly care.

The inadequate work conditions clarified by the lack of available resources, services and materials for the elderly population influence the discouragement of professionals with their own work ${ }^{4}$ and become an obstacle for PHE, ${ }^{15}$ as they go against the belief in transformation and prevent the dialogical relationship, ${ }^{9}$ so that hopelessness and the emphasis on this borderline-situation ${ }^{9}$ become unbearable for workers.

As health professionals are not aware of their own roles as transforming agents of practice for group reflection, they cannot know the inventive and transforming potential of the world, ${ }^{10}$ increased by PHE through dialogue. In this sense, one must be aware of the obstacles and become involved as a team to overcome the traditional concepts in their practices and create a critical culture, which can certainly be achieved through dialogue only.

Thus, health professionals will overcome this when they embrace a mutual partnership in the learning process, working together to seek the transformation ${ }^{9,10,15}$ of practices in elderly 
care. The change is limited to those who choose it, participants of the transformative process. ${ }^{9}$ Doing for the sake of doing, determined by the alienating work process, without the intention of transformation, does not promote change in elderly care. Unfortunately, this reality was found in the present study.

The existing hegemonic health care model, resulting from the part of the service provided to users, where healing actions and the difficulty to perform inter-professional work predominate, hinders the dialogue leading the praxis involved with PHE. ${ }^{16}$ The work process stated, with specific PHE actions, indicates that this is the context of elderly care. To some extent, it is necessary to break away from this work alienation and build health practices aimed at the construction of new health concepts and other health care models ${ }^{15}$ that approach the comprehensiveness of elderly care and consider the remaining factors that influence active and healthy aging - given the current demand for PHC.

Aiming to emphasize alienating work conditions, hierarchical determinations are decisive factors. In this respect, study participants stressed managers' lack of interest with PHE in elderly care and unawareness of the educational roles performed by the NASF, hindering their implementation. The polarized power in work organization decisions are real conditions that exemplify the dominator-dominated or oppressor-oppressed relationship ${ }^{9}$ and, in a way, maintain the actions performed in $\mathrm{PHC}$ under the control of management, thus restricting PHE in elderly care.

As a result, there are routine actions for older adults without resolvability, precisely because those who experience them - PHC professionals - are discouraged by management to reflect over them and find relevant solutions, as moments of emancipating dialogue between the NASF and ESF are hindered. The imbalance between learning through work and its disorganization caused by the city's health management are difficulties that cause the implementation of PHE to fail, ${ }^{11,17}$ with the maintenance of a practice that has little transformative effect on aging conditions.

Additionally, these moments of reflection and dialogue have become impractical with the current $\mathrm{PHC}$ model for elderly care. The emphasis on diagnostic, therapeutic and rehabilitating actions was evident when prioritizing elderly care. Aiming to achieve this, given the demand of older adults, health professionals are fully committed to individual and group care and, for this reason, they cannot reflect on their actions or find new perspectives for their work. This is because the exchange of knowledge that enables the construction of new knowledge ${ }^{9}$ has become restricted.

The affirmation that PHE involves the dynamic and dialectical movement between doing and thinking about doing is essential to transform elderly health practices. Thinking about the practice critically is what can improve this practice.$^{10}$ However, the fact that professionals cannot find a moment to meet each other prevents dialogue and the reflection on the practices performed by them to care for the elderly population.

In contrast, health professionals envision the possibilities of PHE in elderly care shaped by the work context itself. The facilitators experienced by NASF professionals, although specific, were associated with concrete work situations in practice, i.e. when the NASF and the ESF team work together due to the older adults' actual needs. In such cases, as previously described, the ESF was found to be more open and supportive of dialogue. Regardless of routine questions and management principles that hinder the possibility of learning through practice, the group work demonstrated by the union between teams promotes dialogue and, consequently, the practices of $\mathrm{PHE}^{11}$ with positive results for the improvement of care provided to the elderly population.

This shows the key role of PHE. It is precisely during work situations that PHE must take place, not only in specific qualification situations, which do not always make sense to health professionals at such moments. ${ }^{2,3}$ Thus, one's capacity to learn, especially to transform reality, is closely associated with the essence of the reflective practice and availability for dialogue, which creates the dialogical relationship ${ }^{10}$ in PHE for elderly care.

Coincidently, the work performed while one is open to transformation promotes dialogue and brings participants closer together. ${ }^{18}$ However, the existing contradictions about the word "team" found in both analyses (Figures 1 and 2) are part of the complexity of the team's own work. Contradictions exist and are necessary for action-reflection-action, as they lead to participants' awareness ${ }^{9,10}$ during their routine of work and care for the elderly population.

Moreover, when acknowledging the elderly population as a reality in their service, health professionals find out the different dimensions characterizing the essence in practice,${ }^{10}$ causing PHE actions in elderly care to be more effective through work process problematization. ${ }^{2}$ The fact that there is a great demand of older adults in $\mathrm{PHC}$ causes learning through practice to be clearly urgent.

Furthermore, health professionals understand that educational moments in the context of PHE do not necessarily need to occur in the physical space of the UBS, but rather in those spaces that include workers and are a part of their work process. This concept corroborates PHE premise ${ }^{2}$ and explains possible ways to put it into practice in the work routine, indicating Home Visits (HV) to older adults as one such way. ${ }^{17}$

During a HV to an older adult, teaching is experienced by health professionals through practice itself, ${ }^{9}$ facilitating the development of PHE in elderly care and enabling the transformation of practices. Viewed as moments that are full of dialogue, learning and partnership between NASF and ESF professionals, HVs enable exchanges of knowledge and activities.

It is important to understand and emphasize that the teaching-learning process, when referring to PHE, must not be restricted to the transmission of contents and information, ${ }^{2}$ as it is founded on a liberating and problematizing type of education. The experiences of these professionals must be taken into consideration, as they influence health care practices and include values, beliefs and meanings. ${ }^{9}$ In this sense, $\mathrm{HV}$ s were a facilitator for the moment of horizontal and dialogical education in elderly care in the context of PHE. 
Likewise, through the high demand of cases involving older adults, health professionals participating in the ESF follow a dialogical, open, curious and inquisitive approach, i.e. they become epistemologically curious. ${ }^{10}$ This curiosity brings professionals closer together and directs them towards the search for knowledge in elderly care, based on the dialogue and exchange of knowledge with NASF professionals, seeking a type of education which is constantly rebuilt in the praxis, ${ }^{9,10}$ causing matrix support to be effective.

Thus, NASF professionals do not simply play an educational role, as they are not only teaching, but while doing and mediating education, they are learning through dialogue ${ }^{10}$ with ESF professionals. As a result, both become participants in the PHE process and the dialogue promoted by meetings enables the construction of new knowledge and activities in elderly care practices. Meetings are incorporated in the work process of ESF teams and, although incipient in the present study, they were emphasized as necessary. In fact, these meetings are considered to be essential moments for $\mathrm{PHE},{ }^{19}$ as they promote authentic dialogue between the NASF and $\mathrm{ESF}^{9}$ and transform elderly care practices.

Health Education groups are included in the work context and practices in elderly care, enabling professionals to become critical in reality. ${ }^{9}$ However, unfortunately, the development of these groups still revolves around the disease and healing proposal, emphasizing the hegemony of health education and showing the vulnerabilities when educational actions for elderly care are performed and the challenges for the implementation of a practice that promotes health for this population. ${ }^{18}$ Nonetheless, once again study participants revealed that it is precisely at these moments that practices permeated through dialogue are in fact problematized at work among health professionals, enabling conditions for them to transition from naïve knowledge to critical and reflective knowledge.

In the context studied, the support received by management was present through the Programa de Qualificação da Atenção Primária à Saúde (APSUS - Primary Health Care Qualification Program). Created in 2011 by the Paraná State Department of Health, its mission was to organize PHC actions and services in this state. Aiming at this incentive in elderly care, the APSUS designed a specific workshop providing the instruments required by health professionals to plan health care based on risk stratification..$^{20}$ The importance of creating dialogical spaces that promote the exchange of experiences among health professionals was emphasized, aiming to transform practices to meet the demands of the elderly population through group planning and the development of training courses based on problematizing discussions. . $^{18,21,22}$

It is interesting to consider that this incentive came precisely from the city management, which, during non-specific moments of the dialogical meeting between NASF and ESF, discouraged $\mathrm{PHE}$, while promoting normative directives like this. This fact enables us to consider the doctrinal approach of the city management and the low autonomy of local health services to define their specific PHE actions. This reality reveals the indecisive nature of the local management regarding PHE and the distance of its mission, rooted in the concrete reality. ${ }^{3}$

Not disregarding the vertical initiatives of Continuing qualification, workshops and training courses are also capable of qualifying elderly care. However, it is important not to mistake and limit the PHE purposes to courses, taking Continuing Education into consideration. ${ }^{3}$

Thus, moments of PHE regulated by the APSUS could lead health professionals, aiming at reality, to a task where everyone participates in such action, not only to reveal it but also to critically know it, with the purpose of recreating this knowledge. ${ }^{9}$ However, the work process organization developed by PHC workers is what could transform practices, surpassing the transmission of knowledge. Unfortunately, this result was not obtained in the present study.

\section{CONCLUSIONS AND IMPLICATIONS FOR PRACTICE}

Through lexicography, the difficulties and facilitators experienced by NASF professionals to develop PHE in elderly care could be identified. The words "no" and "team" were the most frequent and referred to the difficulties, whereas the words "team" and "elderly" stood out among the facilitators experienced.

It could be concluded that NASF professionals experienced more difficulties than facilitators to develop PHE in elderly care with the ESF. Additionally, these difficulties were associated with the lack or absence of support, instruments and resources required for PHE. The relationship between teams, the home visits, the high demands of elderly cases, the meetings, the groups and also the training courses given by the Department of Health promote PHE in elderly care developed by the NASF, although this is specific and timely.

It should be emphasized that different contents comprising the word clouds could be identified, both the difficulties and facilitators, and that the word "team" permeated both analyses, although with different meanings. As a difficulty, the word "team" meant the absence or lack of involvement of ESF professionals in PHE practices with the NASF, whereas, as a facilitator, the word "team" was associated with positive relationships between teams.

The description of the universe of PHE can contribute to moments of reflection, planning and assessment of educational and health practices for elderly care performed by the NASF. One of the limitations of the present study was the lack of inclusion and participation of professionals included in ESF teams that would, undoubtedly, include new perspectives and views on PHE practices for elderly care performed by the NASF. New studies should be conducted to approach ESF professionals' perspective of this theme. 


\section{REFERENCES}

1. Ministério da Saúde (BR). Secretaria de Atenção à Saúde. Departamento de Atenção Básica. Núcleo de Apoio a Saúde da Família. Ferramentas para a gestão e para o trabalho cotidiano. Brasília (DF): Ministério da Saúde; 2014.

2. Ministério da Saúde (BR). Secretaria de Gestão do Trabalho e da Educação na Saúde. Departamento de Gestão da Educação em Saúde. Política Nacional de Educação Permanente em Saúde. Brasília (DF): Ministério da Saúde; 2009.

3. Mishima SM, Aiub AC, Rigato AFG, Fortuna CM, Matumoto S, Ogata $M N$, et al. Managers' perspective on continuous health education in a region of São Paulo State. Rev Esc Enferm USP [Internet]. 2015; 49(4):665-73. Available from: http://www.scielo.br/scielo. php?pid=S0080-62342015000400665\&script=sci_abstract

4. Andrade RS, Caldas LBSN, Falcão MLP, Goes PSA.Processo de Trabalho em Unidade de Saúde da Família e a Educação Permanente. Trab Educ Saúde [Internet]. 2016; 14(2):505-21. Available from: http://www. scielo.br/scielo.php?pid=S1981-77462016005002101\&script=sci_ abstract\&tlng=pt

5. Santos S, Tonhom SFR, Komatsu RS. Integralidade do cuidado ao idoso na Estratégia Saúde da Família-ESF. CIAIQ2016 [Internet]. 2016; 2:1292-301. Available from: http://proceedings.ciaiq.org/index.php/ ciaiq2016/article/view/886/870

6. Bonfim IG, Bastos ENE, Góis CWL, Tófoli LF. Apoio matricial em saúde mental na atenção primária à saúde: uma análise da produção científica e documental. Interface (Botucatu) [Internet]. 2013 Jan; 17(45):287300. Available from: http://www.scielo.br/scielo.php?script=sci_ abstract\&pid=S1414-32832013005000012\&lng=pt\&nrm=iso

7. Barros TB, Maia ER, Pagliuca LMF. Facilidades e dificuldades na assistência ao idoso na estratégia de saúde da família. Rev Rene [Internet]. 2011 Oct/Dec; 12(4):732-41. Available from: http://pesquisa. bvsalud.org/portal/resource/pt/lil-682322?lang=fr

8. Oliveira AMS, Menezes TMO. A enfermeira no cuidado ao idoso na estratégia saúde da família: sentidos do vivido. Rev Enferm UERJ [Internet]. 2014 Jul/Aug; 22(4):513-8. Available from: http:// www.e-publicacoes.uerj.br/index.php/enfermagemuerj/article/ view/15373/11628

9. Freire P. Pedagogia do Oprimido. $50^{\mathrm{a}}$ ed. Rio de Janeiro: Paz \& Terra 2011.

10. Freire P. Pedagogia da Autonomia: Saberes necessários à prática educativa. 48 ${ }^{\underline{a}}$ ed. Rio de Janeiro: Paz \& Terra; 2014.

11. Viana DM, Nogueira CA, Araújo RS, Vieira RM, Rennó HMS, Oliveira VC. A educação permanente em saúde na perspectiva do enfermeiro na estratégia de saúde da família. Rev Enferm Cent Oeste Min [Internet] 2015 May/Aug; 5(2):1658-68. Available from: http://www.seer.ufsj.edu. br/index.php/recom/article/view/470/868
12. Backes DS, Colomé JS, Erdmann RH, Lunardi VL. Grupo focal como técnica de coleta e análise de dados em pesquisas qualitativas. Mundo Saúde [Internet].2011;35(4):438-42. Available from: http://bvsms.saude. gov.br/bvs/artigos/grupo_focal_como_tecnica_coleta_analise_dados_ pesquisa_qualitativa.pdf

13. Camargo BV, Justo AM. IRAMUTEQ: um software gratuito para análise de dados textuais. Temas Psicol [Internet]. 2013; 21(2):5138. Available from: http://pepsic.bvsalud.org/scielo.php?script=sci_ arttext\&pid=S1413-389X2013000200016

14. Ministério da Saúde (BR). Conselho Nacional de Saúde. Resolução No 466, de dezembro de 2012. Dispõe de Normas Técnicas envolvendo seres humanos. Brasília (DF): Ministério da Saúde; 2012.

15. Oliveira SRG, Wendhausen ALP.(Re)significando a educação em saúde: dificuldades e possibilidades da Estratégia Saúde da Família. Trab Educ Saúde [Internet]. 2014; 12(1):129-47. Available from: http://www. scielo.br/scielo.php?pid=S1981-77462014000100008\&script=sci abstract\&tlng=pt

16. Gigante RL, Campos GWS. Política de formação e educação permanente em saúde no brasil: bases legais e referências teóricas. Trab Educ Saúde [Internet].2016; 14(3):747-63. Available from: http://www.scielo.br/scielo. php?pid=S1981-77462016000300747\&script=sci_abstract\&tlng=pt

17. Lima SAV, Albuquerque PC, Wenceslau LD. Educação permanente em saúde segundo os profissionais da gestão de Recife, Pernambuco. Trab Educ Saúde [Internet]. 2014; 12(2):425-41. Available from: http://www. scielo.br/scielo.php?pid=S1981-77462014000200012\&script=sci_ abstract\&tlng=pt

18. Mendonça FTNF, Santos AS, Buso ALZ, Malaquias BSS. Health education with older adults: action research with primary care professionals. Rev Bras Enferm [Internet]. 2017; 70(4):792-9. Available from: http://www. scielo.br/scielo.php?pid=S0034-71672017000400792\&script=sci_ abstract

19. Barbosa VBA, Ferreira MLSM, Barbosa PMK. Educação permanente em saúde: uma estratégia para a formação dos agentes comunitários de saúde. Rev Gaúcha Enferm [Internet]. 2012 Mar; 33(1):56-63. Available from: http://www.scielo.br/scielo.php?script=sci_arttext\&pid $=$ S1983-14472012000100008

20. Secretaria de Estado da Saúde do Paraná. Oficinas do APSUS. Saúde do Idoso na Atenção Primária à Saúde. Oficina 9. Saúde do Idoso. O APSUS Saúde do Idoso na Atenção Primária à Saúde. Paraná: Secretário de Estado da Saúde; 2014.

21. Miccas FL, Batista SHSS. Permanent education in health: a review. Revista de Saúde Pública [Internet].2014;48(1):170-85. Available from: http://www.scielo.br/pdf/rsp/v48n1/en_0034-8910-rsp-48-01-0170.pdf

22. Mekaro KS, Ogata MN, FrançaY. Concepções das práticas educativas dos enfermeiros da Estratégia Saúde da Família. Ciênc Cuid Saúde [Internet]. 2014 Oct/Dec; 13(4):749-55. Available from: http://periodicos. uem.br/ojs/index.php/CiencCuidSaude/article/view/21942

\footnotetext{
* Manuscript extracted from the dissertation entitled "Attention to the Elderly: Practices of Permanent Education in Health of the Context of the Family Health Support Center", of the Postgraduate Program in Nursing, State University of Maringá, 2018.
} 